\title{
Neurology
}

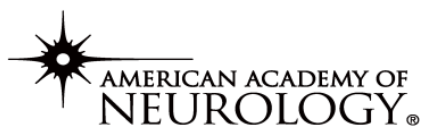

The most widely read and highly cited peer-reviewed neurology journal

\section{Teaching Video NeuroImages: Spontaneous Upbeat-Torsional Nystagmus From Medial} Medullary Infarction

\section{Author(s):}

David Edward Hale, $\mathrm{MD}^{1}$; Kemar Earl Green, $\mathrm{DO}^{2}$

Neurology ${ }^{\circledR}$ Published Ahead of Print articles have been peer reviewed and accepted for publication. This manuscript will be published in its final form after copyediting, page composition, and review of proofs. Errors that could affect the content may be corrected during these processes. 


\section{Corresponding Author:}

Kemar Earl Green

kgreen66@jhmi.edu

Affiliation Information for All Authors: 1. The Johns Hopkins University School of Medicine, Department of Neurology, Baltimore, Maryland, USA; 2. The Johns Hopkins University School of Medicine, Department of Neurology, Division of Neuro-Visual \& Vestibular Disorders, Baltimore, Maryland, USA

\section{Contributions:}

David Edward Hale: Drafting/revision of the manuscript for content, including medical writing for content; Major role in the acquisition of data

Kemar Earl Green: Drafting/revision of the manuscript for content, including medical writing for content; Study concept or design

Number of characters in title: 72

Abstract Word count:

Word count of main text: 126

References: 4

Figures: 1

Tables: 0

Supplemental: Video 1 Video 1 Legend Patient consent form for publication of video

Search Terms: [ 2 ] All Cerebrovascular disease/Stroke, [ 187 ] Ocular motility, [ 192 ] Nystagmus, [ 212 ] Vertigo

Acknowledgements: Thank you Dr. Charlotte Sumner for staffing this patient during hospital admission.

Study Funding: The authors report no targeted funding

Disclosures: D.E. Hale reports no disclosures relevant to the manuscript; K.E. Green reports no disclosures relevant to the manuscript 
A 71-year-old man presented with acute dizziness and right-sided paresthesia. Examination revealed spontaneous torsional nystagmus (top pole of eyes beating to the left) with a milder upbeat component (Video 1), right-sided weakness, and right hemisensory loss. MRI brain showed an acute left medial medullary infarct (Figure 1). Spontaneous upbeat-torsional nystagmus typically results from selective damage to the vertical semicircular canals pathways in the medullary medial longitudinal fasciculus (MLF), often resulting in an ipsilesional-beating torsional nystagmus. ${ }^{1}$ It is important to note that extra-MLF lesions in the brachium conjunctivum and ventral tegmental tract can also produce similar findings (Figure 1). ${ }^{1,2}$ While upbeat-torsional nystagmus is more commonly observed in posterior canal benign paroxysmal positional vertigo, it is elicited by the Dix-Hallpike maneuver and is not continuous or spontaneous.

\section{Appendix 1 Authors}

\begin{tabular}{|l|l|l|}
\hline Name & Location & Contribution \\
\hline David E. Hale Jr., MD & $\begin{array}{l}\text { The Johns Hopkins University School of } \\
\text { Medicine, Baltimore }\end{array}$ & $\begin{array}{l}\text { Drafted and revised the } \\
\text { manuscript for intellectual } \\
\text { content }\end{array}$ \\
\hline Kemar E. Green, DO & $\begin{array}{l}\text { The Johns Hopkins University School of } \\
\text { Medicine, Baltimore }\end{array}$ & $\begin{array}{l}\text { Revised the manuscript for } \\
\text { intellectual content }\end{array}$ \\
\hline
\end{tabular}

[AZ 7.12.2021] 167080 Teaching Slides --http://links.lww.com/WNL/B502

[AZ 7.12.2021] 167080 Video 1 --- http://links.lww.com/WNL/B503 


\section{References}

1. Leigh RJ, Zee DS. The neurology of eye movements. 5th edition. Oxford; New York: Oxford University Press; 2015.

2. Gold, D. Vertical semicircular canal pathways. In: Spencer S. Eccles Health Sciences Library, University of Utah [online]. Available at:

https://collecitons.lib.utah.edu/ark:/87278/s6xq1s4t. Accessed March 1, 2021. 


\section{Figure legend}

Figure Title: Central localizations of spontaneous upbeat-torsional nystagmus

Figure 1 Diffusion-weighted imaging (DWI) revealing restricted diffusion in the left anterior medulla and paramedian left medulla (A) with apparent diffusion coefficient (ADC) correlation (B) suggesting an acute infarct. Pathway imaging (C) adapted from vertical semicircular canal pathways by Gold, D. ${ }^{2}$ MLF and extra-MLF central localizations of spontaneous upbeattorsional nystagmus. Patient's ischemic stroke represented by lightning bolt in the MLF pathway. BC - brachium conjunctivum; VTT - ventral tegmental tract; MLF - medial longitudinal fasciculus; SVN - superior vestibular nucleus; LVN - lateral vestibular nucleus; MVN - medial vestibular nucleus; IV - fourth nerve nucleus; III - third nerve nucleus; INC - interstitial nucleus of Cajal. 


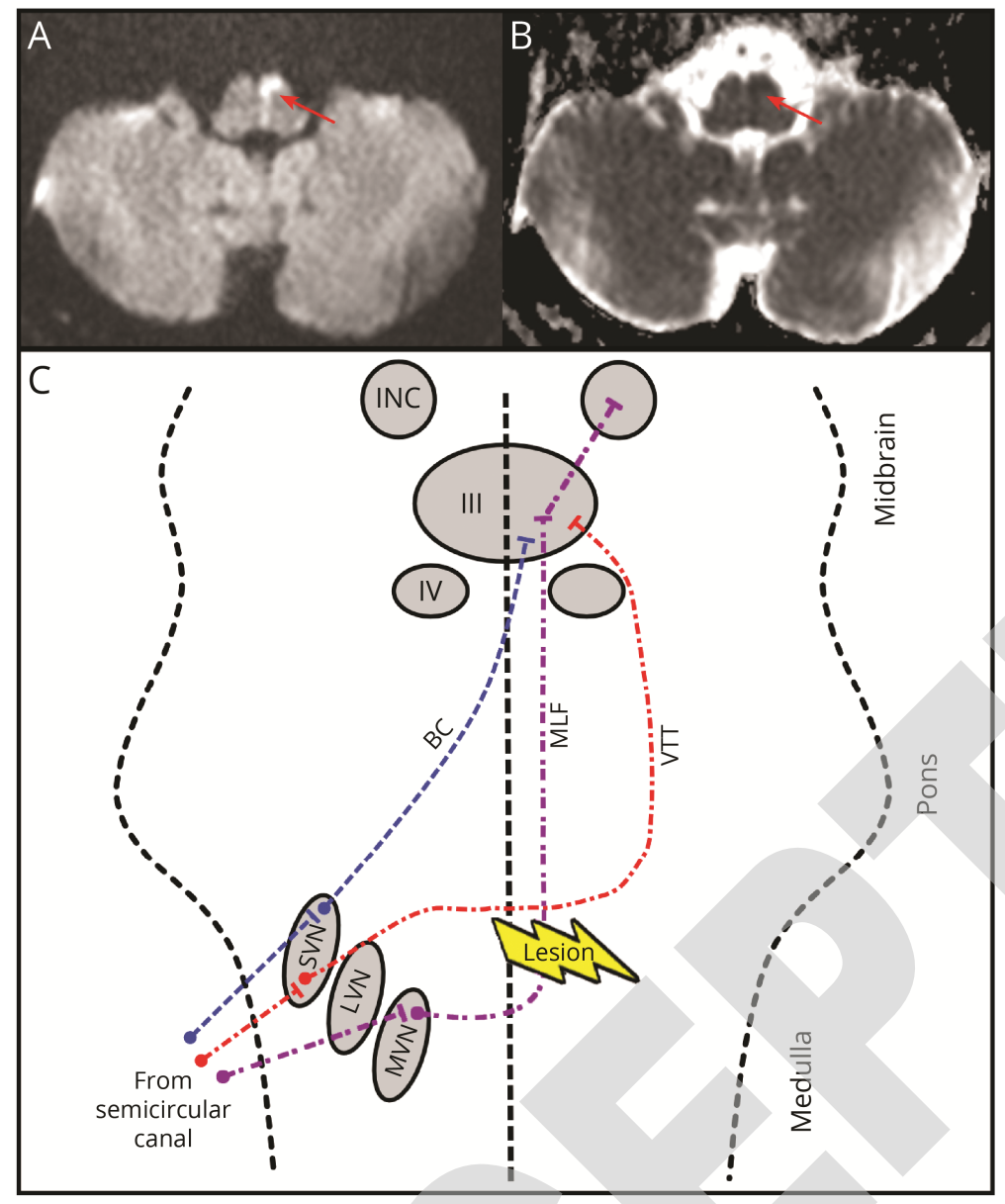

\section{Video legend}

Video 1 showing spontaneous torsional nystagmus (top pole of eyes beating to the left) with a mild upbeat component, and unidirectional torsional nystagmus with top poles beating to the left in both left and right eccentric gaze. 


\title{
Neurology
}

\author{
Teaching Video NeuroImages: Spontaneous Upbeat-Torsional Nystagmus From Medial \\ Medullary Infarction \\ David Edward Hale and Kemar Earl Green \\ Neurology published online August 16, 2021 \\ DOI 10.1212/WNL.0000000000012659
}

\section{This information is current as of August 16, 2021}

Updated Information \&

Services

Subspecialty Collections

Permissions \& Licensing

Reprints including high resolution figures, can be found at: http://n.neurology.org/content/early/2021/08/16/WNL.0000000000012659. citation.full

This article, along with others on similar topics, appears in the following collection(s):

All Cerebrovascular disease/Stroke

http://n.neurology.org/cgi/collection/all_cerebrovascular_disease_stroke Nystagmus

http://n.neurology.org/cgi/collection/nystagmus

Ocular motility

http://n.neurology.org/cgi/collection/ocular_motility

Vertigo

http://n.neurology.org/cgi/collection/vertigo

Information about reproducing this article in parts (figures,tables) or in its entirety can be found online at:

http://www.neurology.org/about/about_the_journal\#permissions

Information about ordering reprints can be found online:

http://n.neurology.org/subscribers/advertise

Neurology ${ }^{\circledR}$ is the official journal of the American Academy of Neurology. Published continuously since 1951, it is now a weekly with 48 issues per year. Copyright (C) 2021 American Academy of Neurology. All rights reserved. Print ISSN: 0028-3878. Online ISSN: 1526-632X.

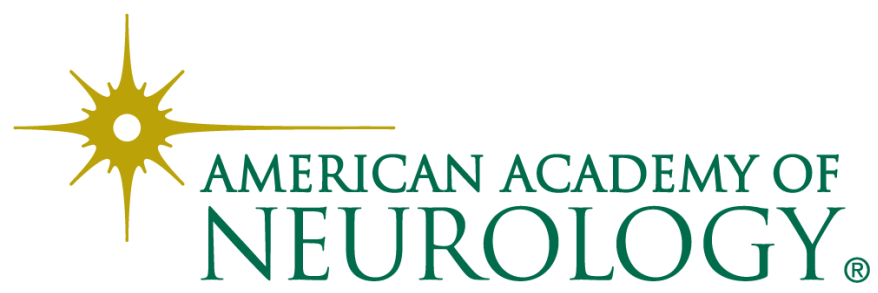

